\title{
EMOSIONELE REAKSIES VAN DIE MOEDER VAN DIE SEKSUEEL MISBRUIKTE KIND NA BEKENDMAKING VAN SEKSUELE MISBRUIK
}

\section{Corinne Strydom, Wilna Stander}

\section{PROBLEEMSTELLING}

Verskeie skrywers, naamlik Vermeulen en Fouché (2006:14) asook Le Roux (2000:36), bevestig dat die werklike statistiek rakende die seksuele misbruik van kinders moeilik bepaalbaar is, aangesien $70 \%$ tot $80 \%$ van alle gevalle nooit aangemeld word nie. Cawood (2004:1) meld dat een uit elke drie dogters en een uit elke vyf seuns in Suid-Afrika onder die ouderdom van 18 jaar seksueel misbruik word. Vermeulen en Fouché (2006:20) maak die opmerking dat die oorgrote meerderheid gevalle van seksuele misbruik binne die gesin- en familiesisteem voorkom, en dit is deur Marshall en Herman (2000:53) bevestig.

Vermeulen en Fouché (2006:19) is van mening dat die seksueel misbruikte kind wat binne die interfamilie-sisteem misbruik word, binne 'n bepaalde konteks van die oortreder afhanklik is. Hill (2001:385) bevestig dat die moeder met gesinsverhoudings en -dinamiek gekonfronteer word, wat waarskynlik sal verbrokkel indien sy die seksuele misbruik bekend sou maak. Dyb, Holen, Steinberg, Roderiguez en Pynoos (2003:940) wys daarop dat ouers intense spanning beleef wanneer hulle kinders se seksuele misbruik bekend word. Gevoelens van hulpeloosheid, woede en vrees is gedokumenteer. Dieselfde skrywer voeg die volgende by: "Hearing about the sexual abuse, testifying in court, hearing the verdict and being exposed in media reports were all rated by the parents as distressing events. The majority of the parents experienced secondary life changes after the alleged sexual abuse." Hierdie navorsing het bevind dat een derde van die ouers wat aan die navorsing deelgeneem het, na 4 (vier) jaar hoë vlakke van Posttraumatiese Stres-sindroom beleef het.

Plummer (2006:1228) is van mening dat ouers 'n rouproses deurmaak, naamlik van ontkenning, skuld, depressie, woede en aanvaarding. Hierdie aspekte word bevestig deur Hill (2001:385) wat opmerk dat "[ $\mathrm{t}]$ he impact on women after finding out about the sexual abuse of their children is serious, and long lasting. This factor is consistently under-estimated by professionals". Dieselfde skrywer meld dat die ouers se emosies wissel van woede, skuld, tot selfs angs. Die lang- en korttermyngevolge vir die moeder van die seksueel misbruikte kind is 'n realiteit binne hierdie konteks.

Rosenthal, Feiring en Taska (2003:642) het bevind dat kinders die emosionele ondersteuning van hul primêre versorgers as uiters belangrik ervaar wanneer hulle seksueel misbruik is.

Navorsing deur Plummer (2006:1234) bevestig dat kinders wat tydens die bekendmaking van seksuele misbruik deur hul moeder ondersteun word, minder emosionele en gedragsproblematiek toon nadat hulle die seksuele misbruik aan hulle onthul het.

Sanders, Cann en Markie-Dadds (2003:155) asook Brits en Joubert (2003:30) bevestig die uiters belangrike en bykans onmeetbare inset wat die moeder behoort te lewer in die seksueel misbruikte kind se vordering na herstel. Die moeder is meermale die primêre fisiese versorger van haar kinders. Die slagoffer se emosionele reaksies en die aard asook gehalte van die hulp wat sy na die bekendmaking van die seksuele misbruik ontvang, sal haar pad na herstel onherroeplik beïnvloed. 
Volgens Hill (2001:386) het die moeders ervaar dat professionele intervensie gefokus het op die moeder se vermoë as ouer om haar kind te beskerm. Geen emosionele ondersteuning is deur die professionele persone wat by die ouer betrokke was, gegee nie. Plummer (2006:1228) meen dat moeders 'n behoefte het aan bykomstige inligting en opvoeding rakende die hantering van hul eie emosionele belewenisse om hul kind na behore te kan bystaan.

Die forensiese maatskaplike werker bevind haar meermale in 'n posisie waar sy die moeder van die seksueel misbruikte kind tydens die forensiese proses moet bystaan. In die Suid-Afrikaanse konteks word forensiese maatskaplike werk gedefinieer as 'n gespesialiseerde veld binne die maatskaplikewerk-praktyk wat gekenmerk word deur die primêre funksie van ekspert getuienislewering (Weyers, 2001:2).

Strydom en Ludwig (2009:333) onderskryf Barker en Branson (2000:16) se mening dat forensiese maatskaplike werkers ten minste 10 (tien) primêre funksies vervul, naamlik getuienislewering as 'n ekspertgetuie in die hof, sistematiese evaluering van individue sodat hierdie inligting aan die hof voorgelê kan word, ondersoek van sake waar moontlike kriminele handelinge plaasgevind het, verstrek die bevindinge aan die owerhede, aanbevelings rakende vonnisoplegging en rehabilitasie van kriminele oortreders, fasilitering van 'n hofbevel rakende 'n opgelegde vonnis, mediasie, getuienislewering rakende professionele standaarde in maatskaplike werk asook opleiding van kollegas. Laastens meld die voormelde skrywers dat 'n forensiese maatskaplike werker die verantwoordelikheid dra om aan sy/haar kliënte en die publiek inligting te verstrek rakende wetlike prosesse asook rakende die implikasies van bepaalde besluitneming. Die kliënte se behoeftes behoort tydens die forensiese proses onder die loep geneem te word.

Uit bogenoemde ontstaan die volgende navorsingsvrae:

- Wat is die emosionele reaksies van die moeders nadat seksuele misbruik van die kind bekend geword het?

- Hoe kan die forensiese maatskaplike werker die moeder tydens die forensiese proses behulpsaam wees?

\section{DOELSTELLING}

Die doelstelling is om die emosionele reaksies van die moeder van die seksueel misbruikte kind na bekendmaking daarvan te bepaal en hoedat die forensiese maatskaplike werker die moeder tydens die forensiese proses behulpsaam kan wees.

\section{METODE VAN ONDERSOEK}

\section{Literatuurstudie}

Volgens Fouché en Delport (2005:124) is die bestudering van relevante literatuur noodsaaklik vir die duidelike formulering van die navorsingsprobleem.

Die Ferdinand Postma Biblioteek van die Noordwes-Universiteit is as hulpbron benut om literatuur en inligting te bekom. Verskeie artikels wat in die vaktydskrifte Child Abuse and Neglect, Child Abuse Review en CARSA gepubliseer is, is bestudeer. Navorsingspublikasies, boeke en tydskrifte is geraadpleeg. Databasisse wat geraadpleeg is, is Social Work Abstracts, Social Science Abstracts, EBSCHO HOST WEB, NEXUS, Repertorium van Suid-Afrikaanse tydskrifartikels en SABINET. 


\section{Empiriese ondersoek}

\section{Die navorsingsontwerp}

Die navorsingsontwerp is die proses waarvolgens data ingewin word om die hipotese ter sprake te ondersoek of die navorsingsdoel te verwesenlik (Nuwe Woordeboek vir Maatskaplike Werk, 1995:37). Die navorsingsontwerp wat gedurende hierdie studie benut is, was die verkennende navorsingsontwerp. Die doel van die verkennende navorsingsontwerp, volgens Babbie (2007:67), is om die onderwerp te verken en inligting en feite in te samel. 'n Literatuur-soektog het geen studie binne die Suid-Afrikaanse konteks oor hierdie spesifieke onderwerp opgelewer nie. Oorsese navorsing wat met betrekking tot verwante onderwerpe bestudeer is, dui wel die emosionele reaksie van die moeder van die seksueel misbruikte kind aan, maar daar moet bepaal word of die bevindinge op die Suid-Afrikaanse samelewing van toepassing is. Die forensiese maatskaplike werker se verantwoordelikheid rakende die opvoeding van en verstrekking van inligting aan kliënte met betrekking tot die forensiese proses binne die SuidAfrikaanse konteks is onbekend.

\section{Navorsingsrespondente}

Die teikengroep van die studie was moeders van kinders wat na bewering seksueel misbruik was. Moeders van kinders uit die teikengroep, is uit die gevallelading van die navorser op 'n niewaarskynlikheidsbasis geselekteer. Die tipe steekproef was doelgerig, aangesien die teikengroep oor bepaalde eienskappe moes beskik. Strydom (2005b:202) meld dat hierdie tipe steekproefmetode “... is based entirely on the judgement of the researcher, in that a sample is composed of elements that contain the most characteristics, representative of typical attributes of the population."

Die geïdentifiseerde teikengroep het uit 'n gesamentlike getal van vyftien (15) bestaan. Aanvanklik sou 29 respondente aan die studie deelneem, maar veertien (14) het hulle aan die navorsing onttrek. Die redes vir onttrekking was aspekte soos verhuising, emosionele impak van die seksuele misbruik op die gesin en onwilligheid van individue om by sodanige navorsing betrokke te raak weens die sensitiwiteit van die onderwerp. Die studie is in Pretoria (Tshwane) gedoen en het vyftien (15) vroue ingesluit. Die respondente het bepaalde eienskappe gemeen gehad, naamlik:

- Moeders van kinders tussen die ouderdomme 3 en 12 jaar wat na bewering seksueel misbruik was.

- Almal was in en om Tshwane, Gauteng, woonagtig.

- Almal was deur maatskaplike werkers van welsynsorganisasies, mediese dokters en sielkundiges in privaatpraktyke na die navorser verwys.

- Die kinders het reeds bekentenisse gemaak van seksuele misbruik of/en daar bestaan mediese bewyse wat op seksuele misbruik dui.

\section{Meetinstrumente}

Vir die doel van hierdie ondersoek is gebruik gemaak van kwantitatiewe navorsing. Barker (2003:354) omskryf dit as volg: "Systematic investigations that include descriptive or inferential statistical analysis. Examples are experiments, survey research, and investigations that make use of numerical comparisons."

'n Toepaslike gedeelte van die Persoonlike Multisiftingsinventaris (PMSI) vraelys van Perspektief Opleidingskollege is benut in die navorsing. Die vraelys is gestandaardiseer en word as betroubaar en geldig geag. Delport (2005:160) is van mening dat “... to obtain valid and reliable data, one must ensure, before implementing the study, that the measurement procedures and the measurement 
instruments to be used, have acceptable levels of reliability and validity. Validity and reliability are two of the most important concepts in the context of measurement".

Hierdie vraelys bestaan uit sewe (7) oorhoofse evalueringsareas, naamlik die positiewe psigososiale funksioneringsareas, die negatiewe psigososiale funksioneringsareas, emosionele funksionering, selfpersepsie, interpersoonlike funksionering, geestelike funksionering en fisiese funksionering. Die voormelde areas beskik oor onderafdelings, wat elke area verder ontleed/verfyn. Vir die doel van die navorsing, is besluit om slegs eersgenoemde vier (4) areas te benut, aangesien die geïdentifiseerde areas uitsluitlik op die individu se emosionele funksionering ingestel is. Die betroubaarheid en geldigheid van hierdie meetinstrument word nie ingeboet deur die weglating van sekere areas nie. Die aangepaste vraelys het dus die moeder van die seksueel misbruikte kind se emosionele funksionering op 'n gestandaardiseerde wyse gemeet.

'n Selfontwerpte vraelys wat uit oop en geslote vrae bestaan, is deur die navorser opgestel om bykomstige inligting te bekom. Aangesien die studie verkennend was, was gestandaardiseerde meetinstrumente rakende sekere vrae wat binne die studie beantwoord moes word, nie beskikbaar nie. Die vraelys is na aanleiding van soortgelyke bestudeerde vraelyste ontwerp. Die selfontwerpte vraelys bestaan eerstens uit persoonlike inligting, naamlik die ouderdom van die moeder, die ouderdom van die kind, die moeder se huwelikstatus, die moeder se verhouding met die oortreder, taalvoorkeur en etnisiteit. Daarna is die moeder versoek om haar belewenisse rakende die inligting wat deur die forensiese maatskaplike werker verstrek is weer te gee. Bepaalde inligting is verder ingesamel ten einde die doeltreffendheid van die forensiese proses te evalueer.

\section{Navorsingsprosedures}

Die selfontwerpte vraelys asook die PMSI-vraelys, is deur twee persone wat oor soortgelyke kenmerke as die respondente beskik, ingevul. Volgens Strydom (2005c:209) is dit belangrik vir die navorser om die meetinstrumente vooraf te toets. Daar is veral gefokus op die relevansie en toepaslikheid van vrae soos vervat in die selfontwerpte vraelys, aangesien die vraelys nog nooit voorheen gebruik is nie. Voortoetsing van vraelyste kan die navorser help om onduidelike asook dubbelsinnige vrae uit te skakel. Die tydsaspek, as faktor rakende die invul van die vraelyste, was ook binne die voortoetsprosedure in aanmerking geneem. Nadat die nodige aanpassings aan die vraelyste gemaak is, het die navorser telefonies met die respondente kontak opgeneem met die doel om 'n geskikte tyd en lokaal te bepaal. Twee groepe, met agt (8) en sewe (7) lede onderskeidelik, is tydens twee afsonderlike geleenthede versoek om beide die gestandaardiseerde en selfontwerpte vraelys in te vul. Die navorser het elke groep versoek om die geadministreerde vraelys in te vul. Sodoende is die benodigde inligting ingesamel. Delport (2005:169) meen dat, "[i]n this case respondents who are present in a group, each complete a questionnaire on their own. Preferably, each respondent should receive the same stimulus and complete his own questionnaire without discussion with the other members of the group". Die vraelyste is privaat binne die groepsituasie ingevul, aangesien dit inligting van die respondente verlang het wat die individu se identiteit kon verraai.

\section{Dataverwerking}

Die navorser het Perspektief Opleidingskollege se gerekenariseerde program benut ten einde die gestandaardiseerde vraelyste van Perspektief Opleidingskollege te verwerk. Kruger, De Vos, Fouché en Venter (2005:217) meld dat kwantitatiewe data-analise vergemaklik word deurdat gerekenariseerde sagteware daarvoor benut word. Die selfontwerpte vraelys het beide oopantwoord- en geslote vrae, wat die navorser self verwerk het, bevat. 


\section{Etiese aspekte}

Barker en Branson (2000:16) meld dat "[f]orensic social workers maintain with their own clients relationships that uphold the letter and spirit of the law and the ethical principles of their profession". Etiese aspekte is deurlopend geëvalueer, en is tydens die uitvoering van bepaalde stappe in ag geneem.

Strydom (2005a:58-67) onderskei verskeie etiese kwessies wat binne die navorsingsproses van belang is:

- Respondente moet ingelig word oor die doel van die navorsing. In hierdie ondersoek was telefonies met die respondente geskakel ten einde hulle oor die navorsing in te lig. 'n Dekbrief, wat inligting oor die navorsing bevat het, is tydens die groepsituasie aan die respondente oorhandig.

- Neuman (2000:283) waarsku dat die skending van die privaatheid van die respondente onder geen omstandighede mag plaasvind nie. Alhoewel die respondente binne 'n groepsituasie die vraelyste ingevul het, was al die respondente se privaatheid binne die groep verseker.

- Die finale verslag moet objektief, akkuraat en duidelik wees en moet alle noodsaaklike inligting verstrek. Die ondersoeker het die resultate objektief en akkuraat verwerk. Tekortkominge en leemtes, asook foute, is in die navorsingsverslag aangedui.

- Respondente sal toegang verkry tot die bevindinge van die verslag. Daar is aan respondente gestel dat hulle na afhandeling van die studie toegang tot die verslag sal hê.

- Etiese goedkeuring is van die Etiekkomitee van die Potchefstroomkampus van die Noordwes-Universiteit verkry. Die Etiese verwysingsnommer is NWU-00027-09-S1.

\section{BEVINDINGE VAN DIE NAVORSING}

Hierdie inligting is verkry deur 'n gestandaardiseerde meetinstrument van Perspektief Kollege asook ' $n$ vraelys wat deur die navorser self ontwerp is. Vervolgens word die bevindinge aan die hand van die gestandaardiseerde metingskaal en die selfontwerpte vraelys uiteengesit.

\section{Profiel van respondente}

'n Profiel van die respondente word kortliks weergegee met die doel om 'n beeld te verkry van die moeders wat aan die ondersoek deelgeneem het. Die inligting kan dan ook 'n aanduiding gee van die omstandighede waarin die deelnemers hulle bevind het en die mate waarin die seksuele misbruik van hul kind hul lewensomstandighede beïnvloed het.

Die totale aantal respondente wat aan die navorsing deelgeneem het, was vyftien (15). Die meerderheid respondente, naamlik $9(60 \%)$, het in die ouderdomsgroep 30 tot 39 jaar voorgekom terwyl daar $3(20 \%)$ in die ouderdomsgroep 40 tot 49 jaar, 2 (13\%) in die ouderdomsgroep 50 tot 59 jaar en $1(6.6 \%)$ in die ouderdomsgroep 20 tot 29 jaar voorgekom het.

Die meerderheid kinders wat in die betrokke studie ter sprake gekom het, wat seksueel misbruik is, was in die ouderdomsgroep 3 tot 6 jaar, naamlik 10 (66.6\%). Die ouderdomsgroep tussen 7 en 10 jaar het 3 (20\%) kinders opgelewer. Twee (13\%) kinders in die ouderdomsgroep 11 tot 13 jaar is by die studie betrek.

Die meerderheid respondente is geskei, naamlik 7 (46.6\%). Binne die groep van die geskeide moeders is 4 uit die 7 kinders deur hulle biologiese vader misbruik (57\%). Uit die 3 oorblywende 
kinders van die geskeide moeders is $1(14.2 \%)$ deur 'n grootvader aan vaderskant misbruik, $1(14.2 \%)$ deur'n grootvader aan moederskant en $1(14.2 \%)$ deur'n stiefmoeder se seun.

Die tweede meeste respondente, naamlik 6 (40\%), was getroud. Die helfte van die kinders (van getroude moeders) wat in hierdie groep val, naamlik $3(50 \%)$ uit die groep van 6 , is deur die grootvaders aan moederskant misbruik. Uit die 3 oorblywende kinders van die getroude moeders is $1(16.6 \%)$ deur 'n loseerder misbruik, $1(16.6 . \%)$ deur 'n familielid en $1(16.6 \%)$ deur'n grootvader aan vaderskant.

Laastens was $2(13.3 \%)$ van die respondente wat aan die navorsing deelgeneem het, in 'n saamleef verhouding betrokke. Een (1) van die kinders uit die groep is deur hul biologiese vader misbruik (nie die moeder se saamleefmaat nie) en die ander kind deur die biologiese vader se vriende (nie die moeder se saamleefmaat nie).

Hierdie inligting is belangrik omdat die verhouding waarin die seksueel misbruikte kind met die oortreder staan, die intensiteit van die moeder se emosionele reaksie kan beïnvloed, asook die trauma wat sy na bekendmaking van die oortreding beleef. Volgens Hill (2001:385) maak die moeder van die seksueel misbruikte kind 'n verliesproses deur waarvan die aanvanklike reaksie skok is, naamlik "[f]or those whose partner was the abuser there was an added shock". Jackson (2008:44) is van mening dat "[t]he disclosure of sexual abuse is known to create a period of crisis in any family. However, the child and the mother are even more burdened and traumatized when the perpetrator is a person who the child and the mother trust".

Wanneer die seksuele oortreder die vader van die kind is, beleef die moeder gevoelens van verwarring, verlatenheid, skuld, magteloosheid, hulpeloosheid en vrees. Sy blameer haarself vir die misbruik, en aanvaar verantwoordelikheid daarvoor om die gesin behoue te laat bly. Moeders wat hul verhouding met die oortreder wil verbreek om daardeur hul kinders te beskerm, trek aan die kortste ent as hulle emosioneel en finansieel van die oortreder afhanklik is (Willingham 2007:67).

Vervolgens meen Smit (2007:116) dat "[t]he impact of child sexual abuse on the mother is one of loss. Mothers whose partners have sexually abused their children, experience endless, mutiple ongoing and unremitting losses".

Beskikbare literatuur bevestig dat die emosionele reaksie van die moeder van die kind wat binne die gesin of familie misbruik word, beïnvloed kan word deur:

- 'n geskiedenis van seksuele misbruik as kind. Moeders wat as kinders seksueel misbruik is, toon hoër vlakke van trauma as moeders wat met geen geskiedenis van seksuele misbruik presenteer nie.

- die mate van ondersteuning wat die moeder ontvang. Ondersteuning deur familielede, vriende en die gemeenskap is waardevol. Moeders met 'n sterk ondersteunende netwerk is toegerus vir die verwerking van die spanning wat deur 'n bekentenis van seksuele misbruik meegebring word.

- die moeders se inherente vermoë om emosionele spanning te kan hanteer. Interne egokragte en die vermoë om aanpassings te kan hanteer word by hierdie faktor ingesluit (HiebertMurphy, 1998:424; Smit, 2007:122; Willingham, 2007:10).

Al die respondente, dus $15(100 \%)$ was Afrikaanssprekend. Die meerderheid respondente, naamlik 14 (93.3\%), was blank, terwyl $1(6.6 \%)$ 'n kleurling was. 


\section{Emosionele reaksies van die moeder}

Die emosionele reaksies van die moeder is na aanleiding van die gestandaardiseerde metingskaal ondersoek. Faul en Hanekom (2006:3) beskryf die Persoonlike Multisiftingsinventaris as 'n papieren-pen selfevaluering om kliënte se sterkpunte en probleemareas op 33 verskillende areas van persoonlikheid, emosionaliteit en interpersoonlike, geestelike en psigiese funksionering te meet. Die Persoonlike Multisiftingsinventaris word primêr gebruik as ' $\mathrm{n}$ assesseringsinstrument wat deel uitmaak van die terapeutiese intervensie met kliënte. Die Cronbach Alpha-betroubaarheid en eksploratiewe faktoranalises het uitgewys dat die gestandaardiseerde vraelys betroubaar en konstrukgeldig is. Met die Persoonlike Multisiftingsinventaris is die positiewe psigososiale funksioneringsareas, die negatiewe psigososiale funksioneringsareas, die emosionele funksioneringsareas en selfpersepsie areas van die deelnemers gemeet.

Data is in 'n opsommende verslag verwerk en saamgevoeg. 'n Persentasie word aan elke area en onderafdelings van areas toegeken wat as faktore bekend staan. Die persentasies wat verkry is, word onder die kategorie funksionering ingedeel, naamlik:

- Waarskuwingsarea. ' $n$ Waarskuwingsarea dui daarop dat professionele ingryping dringend benodig word met betrekking tot die gemete area of faktor.

- Onderaktivering. Onderaktivering van 'n area of faktor dui daarop dat selfontwikkeling binne die area of faktor nodig is. Selfontwikkeling kan deur middel van berading, lesings of handleidings plaasvind.

- Optimale aktivering. Optimale aktivering binne 'n area of faktor dui daarop dat geen hulp benodig word nie.

\section{FIGUUR 1 \\ POSITIEWE PSIGOSOSIALE FUNKSIONERINGSAREA}

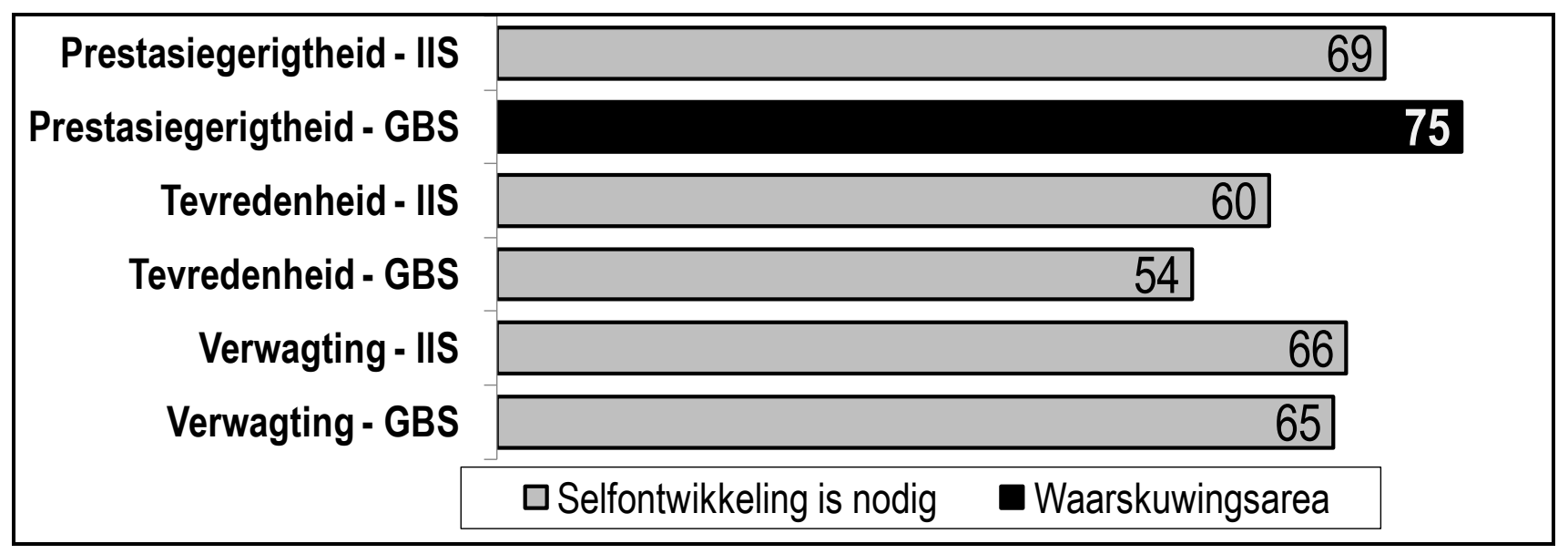

Die skaal is soos volg:

Totaal tussen $73 \%$ en $79 \%$ = waarskuwingsarea

Totaal minder as $73 \%=$ onderaktivering - behoefte aan selfontwikkeling

Totaal van meer as $79 \%=$ optimale aktivering - geen hulp nodig nie

Hierdie positiewe psigososiale funksioneringsarea is in drie (3) areas onderverdeel, met elke area wat onderverdeel is met betrekking tot innerlike belewenisse (IIS) en gedrag (GBS) onderskeidelik, soos aangedui in Figuur 2. Voormelde impliseer dat die metingskaal onderverdeel is en wel uit ses (6) faktore bestaan wat binne hierdie spesifieke funksioneringsarea gemeet is. 


\section{- Prestasiegerigtheid: Innerlike belewenis (IIS)}

Die groep het 'n persentasie van 69 behaal, wat daarop dui dat daar 'n behoefte aan selfontwikkeling voorkom. Die respondente se innerlike belewenis van doelgerigtheid, selfmotivering en die behoefte om die self te ontwikkel is beperk. Die respondente beskik nie altyd oor die nodige deursettingsvermoë om verantwoordelikheid vir hulleself te aanvaar nie. Hulle innerlike dryfkrag is soms beperk.

\section{- Prestasiegerigtheid: Gedrag wat daarop dui (GBS)}

Die groep het 'n persentasie van 75 behaal, wat hierdie konstruk as 'n waarskuwingsarea aandui. Aangesien prestasiegerigtheid (GBS) die hoogste geaktiveerde konstruk is, kan die afleiding gemaak word dat respondente se gedrag daarop dui dat hulle oor beperkte organisatoriese vermoëns en beperkte selfvertroue of dryfkrag beskik, en geen positiewe toekomsperspektief het nie.

\section{- Tevredenheid: Innerlike belewenis (IIS)}

Die groep het 'n persentasie van 60 behaal, wat daarop dui dat daar 'n behoefte aan selfontwikkeling voorkom. Dit ontbreek hulle soms aan die innerlike belewenis van tevredenheid, geluk, vriendelikheid en gemoedsrus. Hulle vind dat hul omstandighede hul innerlike belewenis van geluk met tye negatief beïnvloed.

\section{- Tevredenheid: Gedrag wat daarop dui (GBS)}

Die groep behaal 'n persentasie van 54, wat impliseer dat daar 'n behoefte aan selfontwikkeling in hierdie funksioneringsarea voorkom. Die respondente se gedrag toon soms 'n gebrek aan die volgende elemente: sinvolle benutting van vrye tyd, humor, interaksie met ander, verantwoordelike en weldeurdagte put van plesier uit die lewe. Die respondente moet die oorsake van hierdie belewenisse identifiseer en vaardighede moet ontwikkel word ten einde leemtes aan te vul.

\section{- Verwagting: Innerlike belewenis (IIS)}

Die groep behaal 'n persentasie van 66, wat daarop dui dat daar'n behoefte aan selfontwikkeling in hierdie area blyk te wees. Die respondente verloor soms hoop en is soms pessimisties oor hul toekoms. Dis soms moeilik vir hulle om kalm te bly en hulle is geneig om op die negatiewe elemente in hul omstandighede te fokus. Die respondente moet die oorsake van die negatiewe innerlike belewenisse identifiseer sodat groei en ontwikkeling kan plaasvind.

\section{- Verwagting: Gedrag wat daarop dui (GBS)}

Die groep behaal 'n persentasie van 65 , wat daarop dui dat daar 'n behoefte aan selfontwikkeling in hierdie area voorkom. Die respondente help ander selde om sukses te behaal. Hulle reik nie meer altyd na ander uit nie en tree selde beskermend teenoor ander op. Hulle luister nie meer graag na ander se probleme nie en praat ander nie maklik moed in nie. Hulle waag min en vind dit moeilik om oplossings te vind omdat hulle nie meer positief na moeilike omstandighede kyk nie. Die respondente moet die oorsake identifiseer sodat hulp verleen kan word en ontwikkeling kan plaasvind.

Die gevolgtrekking waartoe geraak kan word, is dat die respondente 'n behoefte aan selfontwikkeling toon rakende vyf (5) van die ses (6) faktore wat binne die positiewe psigososiale funksioneringsareas gemeet is, naamlik prestasiegerigtheid (innerlike belewenis), tevredenheid (beide innerlike belewenis en gedrag wat daarop dui) asook verwagting (gedrag wat daarop dui en hul innerlike belewenis). Die respondente benodig professionele hulp ten opsigte van prestasiegerigtheid, wat gedrag bepaal. Aangesien vyf (5) uit die ses (6) konstrukte ondergeaktiveer is, kan die afleiding gemaak word dat die respondente binne hierdie area geremd funksioneer. 


\section{Negatiewe psigososiale funksioneringsarea}

FIGUUR 2

NEGATIEWE PSIGOSOSIALE FUNKSIONERINGSAREA

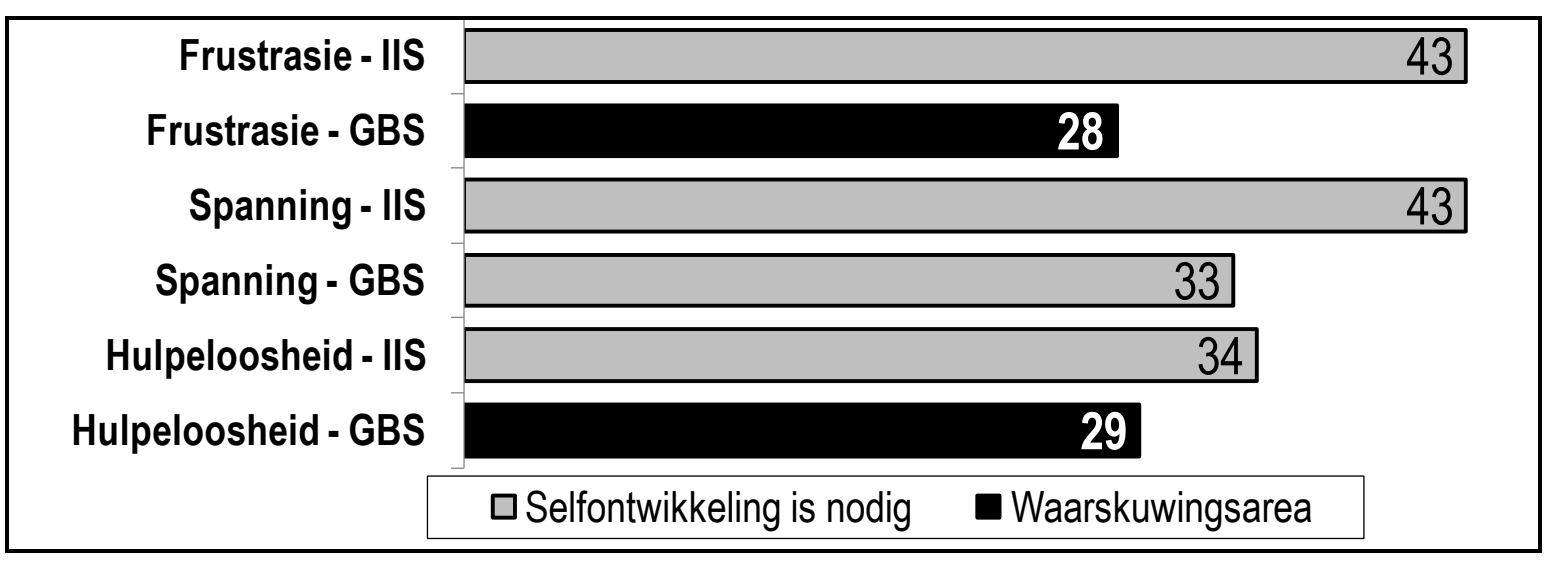

Die skaal is soos volg:

Totaal tussen $22 \%$ en $29 \%$ = waarskuwingsarea

Totaal meer as $29 \%=$ ooraktivering - behoefte aan selfontwikkeling

Totaal minder as $22 \%=$ optimale aktivering - geen hulp word benodig nie

Die negatiewe psigososiale funksioneringsarea is in drie (3) dele onderverdeel, met elke area wat onderverdeel is met betrekking tot 'n meting wat op innerlike belewenisse (IIS) en gedrag (GBS) onderskeidelik dui. Voormelde impliseer dat die metingskaal onderverdeel is en wel uit ses (6) faktore bestaan wat binne hierdie spesifieke funksioneringsarea gemeet is, soos aangedui in Figuur 3.

\section{- Frustrasie: Innerlike belewenis (IIS)}

Die groep behaal 'n persentasie van 43. Die respondente se innerlike belewenis van frustrasie dui op 'n gevoel van onvergenoegdheid. Dit blyk dat hulle nie altyd die onderbreking van doelgerigte aksies as gevolg van probleme in hulself en hul omgewing goed hanteer nie en dat hulle soms toelaat dat dit hulle verhinder om hulle aspirasies in die lewe te verwesenlik. Ervarings soos woede, frustrasie, irritasie, ongeduld, verbittering en agterdog maak soms deel uit van hulle beleweniswêreld. Hulle moet die oorsake hiervan sowel as die areas waar selfontwikkeling moet plaasvind, identifiseer. Smit (2007:120) meld dat "[d]enial and anger are responses that protect the self from the impact of child sexual abuse". Bogenoemde skrywer meld voorts dat die moeder agterdogtig is, aangesien sy vrees dat haar kind weer in die toekoms seksueel misbruik kan word.

\section{- Frustrasie: Gedrag wat daarop dui (GBS)}

Die groep behaal 'n persentasie van 28, wat beteken dat hierdie faktor 'n waarskuwingsarea aandui, soos aangetoon in Figuur 3. Jackson (2008:68) beskryf woede en frustrasie as 'n fase binne die rouproses. Sy is van mening dat "[m]others of sexually abused children sometimes became angry and frustrated because of their inability to prevent the abuse". Aangesien frustrasie (IIS) oorgeaktiveer is en frustrasie (GBS) in die waarskuwingsarea voorkom, dui dit daarop dat die respondente poog om hul belewenis van frustrasie te onderdruk.

\section{- Spanning: Innerlike belewenis (IIS)}

Die groep behaal'n persentasie van 43, wat daarop dui dat daar'n behoefte aan selfontwikkeling in hierdie area voorkom. Die respondente se innerlike belewenisse word soms gekenmerk deur 
'n onvermoë om spanning binne die omgewing te hanteer. Gevoelens van paniek, angs, spanning, oorlading, bekommernis en uitbranding kom voor. Smit (2007:120) meen dat “... the reaction by mothers after disclosure of child sexual abuse must be acknowledged in the light of their extreme stress following disclosure...". Dyb et al. (2003:940) asook Jinich en Litrownik (1999:176) bevestig die voorkoms van geweldige spanning by die moeders van die seksueel misbruikte kind wanneer die kind se misbruik aan die lig kom.

\section{- Spanning: Gedrag wat daarop dui (GBS)}

Die groep behaal'n persentasie van 33, wat daarop dui dat daar'n behoefte aan selfontwikkeling rakende hierdie faktor voorkom. Bepaalde eienskappe maak soms deel uit van die respondente se gedragspatroon deurdat hulle soms onseker, buierig, paniekerig, angstig en senuagtig voorkom. Hulle kan ook fisiese simptome soos hoof- en/of spierpyne en slaaploosheid ondervind. Hulle moet die vaardigheid ontwikkel om hul spanning doeltreffender te bestuur. Die respondente behoort professionele advies in te win asook berading rakende hierdie aspekte te ontvang. Willingham (2007:8) meen dat simptome van depressie by die moeder van die sesueel misbruikte kind voorkom, maar dat navorsing hieroor nie vasgestel het of die simptome van depressie alreeds teenwoordig was voor die bekendmaking van seksuele misbruik nie.

\section{- Hulpeloosheid: Innerlike belewenis (IIS)}

Die groep behaal'n persentasie van 34, wat daarop dui dat daar'n behoefte aan selfontwikkeling rakende hierdie faktor voorkom. Die respondente het 'n punt in hul funksionering bereik waar hulle soms beleef dat, wat hulle ook al doen, nie meer saak maak nie en dat hulle op geen wyse hul omgewingsfaktore in hul lewe kan beheer nie. Hulle ervaringswêreld is soms negatief en sentreer om gevoelens van verwerping, swaarmoedigheid, doelloosheid, magteloosheid, eensaamheid en 'n gevoel dat niks sin inhou nie. Hulle moet die oorsake hiervan identifiseer, sowel as die areas waar groei en ontwikkeling kan plaasvind. Willingham (2007:8) meen dat simptome van depressie by die moeder van die seksueel misbruikte kind voorkom, maar dat navorsing hieroor nie vasgestel het of die simptome van depressie alreeds voor die bekendmaking van seksuele misbruik teenwoordig was nie.

\section{- Hulpeloosheid: Gedrag wat daarop dui (GBS)}

Die groep behaal 'n persentasie van 29, wat daarop dui dat die respondente hulle in die waarskuwingsarea bevind. Die respondente se gedragspatrone toon 'n gebrek aan doelgerigte aktiwiteite, aan humor, aan deursettingsvermoë en aan deelname. Hulle is geneig om sosiaal te onttrek en hanteer situasies vanuit'n negatiewe ingesteldheid sodat 'n neerdrukkende atmosfeer ontstaan.

Die gevolgtrekking waartoe geraak kan word, is dat die respondente 'n behoefte aan selfontwikkeling binne vier (4) van die faktore wat binne die negatiewe psigososiale areas gemeet word, toon, naamlik frustrasie (innerlike belewenis), spanning (beide innerlike belewenis en gedrag wat daarop dui) asook hulpeloosheid (innerlike belewenis). Die respondente benodig professionele intervensie rakende die areas frustrasie en hulpeloosheid, wat gedrag bepaal. Die moeder van die seksueel misbruikte kind beleef hulpeloosheid en is bekommerd oor die toekoms van haar kinders. Gevoelens van hulpeloosheid word voorts ervaar omdat die moeder meen dat sy haar ouerlike pligte rakende haar seksueel misbruikte kind nie nagekom het nie (Jackson, 2008:70). Aldus Smit (2007:120) beleef die moeder dat “... powerlessness creates the feeling for non-abusive parents that they are not directing their own lives anymore but are subject to events outside their control". Willingham (2007:37) bevestig gevoelens van hulpeloosheid en magteloosheid waarmee die moeder van die seksueel misbruikte kind presenteer. 
FIGUUR 3

EMOSIONELE FUNKSIONERING

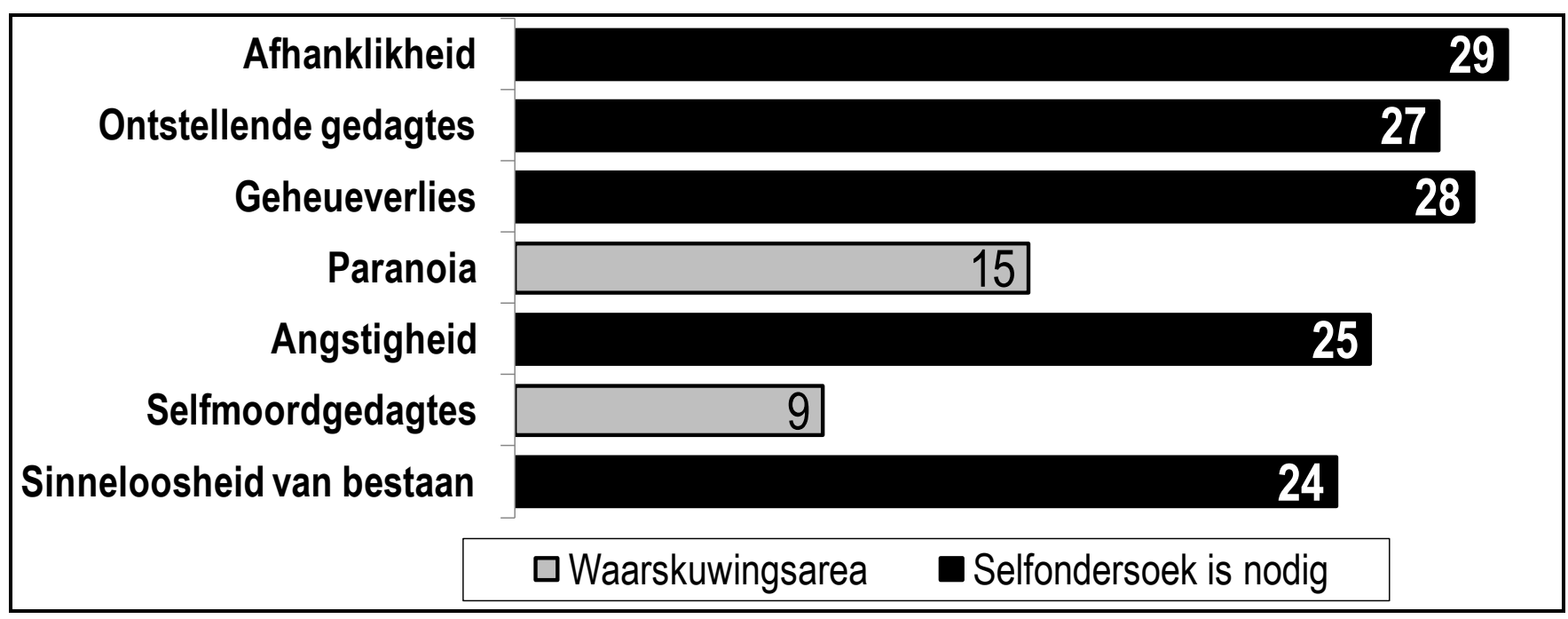

Die skaal is soos volg:

Totaal tussen $17 \%$ en $21 \%$ = waarskuwingsarea

Totaal van meer as $22 \%=$ ooraktivering - behoefte aan selfontwikkeling

Totaal van minder as $17 \%=$ optimale aktivering - geen hulp word benodig nie

Die emosionele funksioneringsarea is in sewe (7) areas onderverdeel, soos aangedui in Figuur 3.

\section{- Afhanklikheid}

Die respondente behaal 'n persentasie van 29 in hierdie area. Gemelde impliseer dat daar 'n behoefte aan selfontwikkeling in hierdie area voorkom deurdat die respondente soms iemand/iets nodig het om die lewe te kan hanteer, om hulle te ondersteun en om probleme te hanteer. Hulle kan druk nie altyd selfstandig hanteer nie. Hulle moet die oorsake hiervan identifiseer sowel as die areas waarin hulle moet groei en ontwikkel. Jackson (2008:59) meld dat 'n studie deur Massat en Lundy bevind het dat “... parents who have children that experienced intra-familial sexual abuse, were more likely to have significant relationship losses, reduced income, increased dependence ... following the disclosure".

\section{- Ontstellende gedagtes}

Die respondente behaal 'n persentasie van 27 in hierdie area. Dit impliseer dat daar 'n behoefte aan selfontwikkeling in hierdie area voorkom. Die respondente presenteer met idees en gedagtes wat hulle ontstel. Daar moet geïdentifiseer word waarom hulle deur ontstellende gedagtes geteister word. Konsultasies met 'n professionele berader word aanbeveel.

\section{- Geheueverlies}

Die respondente behaal 'n persentasie van 28 in hierdie area, wat impliseer dat daar 'n behoefte aan selfontwikkeling ten opsigte daarvan voorkom. Hulle vergeet veelvoudige opdragte maklik. Identifisering van die rede waarom hulle geheueverlies ondervind, is noodsaaklik. Om dit te doen, word 'n konsultasie met 'n professionele berader aanbeveel. 


\section{- Paranoia}

Die respondente behaal 'n persentasie van 15 in hierdie area. Vermelde dui daarop dat geen hulp in hierdie area benodig word nie.

\section{- Angstigheid}

Die respondente behaal 'n persentasie van 25 in hierdie area. Vermelde dui daarop dat selfontwikkeling in hierdie area benodig word. Wanneer die moeder bewus word of bewus gemaak word van die seksuele misbruik van haar kind, is die aanvanklike reaksie skok. Smit (2007:120) is van mening dat die moeder bykomende angs kan ervaar wat haar immobiliseer en toepaslike optrede aan bande lê.

Willingham (2007:36) meen dat moeders van seksueel misbruikte kinders “... experience general psychological stress to clinical symptoms of depression, anxiety and Post Traumatic Stress Disorder".

\section{- Sinloosheid van bestaan}

Die respondente behaal $24 \%$ in hierdie area, wat impliseer dat daar 'n behoefte aan selfontwikkeling ten opsigte daarvan voorkom. Die respondente het soms geen doel in die lewe nie en hulle voel dan dat hulle geen bydrae daartoe kan lewer om van die wêreld 'n beter plek te maak nie. Hulle leer nie altyd uit dit wat met hulle gebeur nie en hulle kom nie altyd struikelblokke in hul lewe te bowe nie. Hulle gee soms hul drome vir hul lewe op en kan dan nie ander help om geluk te smaak nie.

\section{- Selfmoordgedagtes}

Die respondente behaal 'n persentasie van 9 in hierdie area, wat impliseer dat geen hulp ten opsigte daarvan benodig word nie.

Die gevolgtrekking waartoe geraak kan word, is dat die respondente 'n behoefte aan selfontwikkeling in die areas van afhanklikheid, ontstellende gedagtes, geheueverlies en sinloosheid van hul bestaan toon.

\section{SELFPERSEPSIE-AREA}

\section{FIGUUR 4}

SELFPERSEPSIE

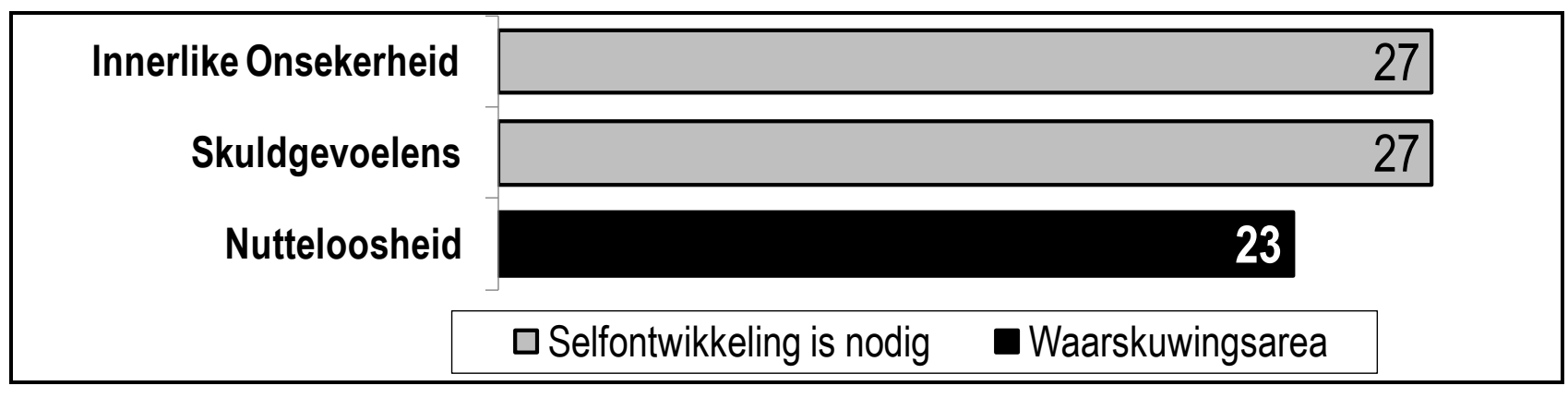

Die skaal is soos volg:

Totaal tussen $21 \%$ en $25 \%=$ waarskuwingsarea

Totaal van meer as $25 \%=$ ooraktivering - behoefte aan selfontwikkeling

Totaal van minder as $21 \%=$ optimale aktivering - geen hulp word benodig nie

Die selfpersepsie-area is in drie (3) areas onderverdeel, soos in Figuur 4 aangedui. 


\section{- Innerlike onsekerheid}

Die respondente behaal 'n persentasie van 27, wat daarop dui dat daar 'n behoefte aan selfontwikkeling in hierdie funksioneringsarea voorkom. Die respondente beleef soms 'n gebrek aan sekuriteit in hul verhoudings en is bang om emosioneel seer te kry. Hulle voel soms bedreig deur hul omstandighede en vrees soms die toekoms. Hulle is soms bang vir mislukking en verwerping. Die beste benadering sou wees om te identifiseer presies wat die oorsprong van die gebrek aan sekuriteit is. Konsultasies by 'n professionele berader word aanbeveel. Moeders beleef innerlike onsekerheid na die onthulling van die seksuele misbruik van hul kind en twyfel oor hul eie ouerlike vaardighede (Willingham, 2007:54).

\section{- Skuldgevoelens}

Die respondente behaal 'n persentasie van 27, wat daarop dui dat daar 'n behoefte aan selfontwikkeling in hierdie funksioneringsarea voorkom. Die respondente bestuur hulleself nie altyd verantwoordelik nie en neem soms die blaam op hulle vir alles wat verkeerd loop. Die beste benadering sou wees om die presiese oorsaak van die skuldgevoelens te identifiseer. Konsultasie met 'n professionele berader sou nodig wees. Verskeie skrywers, naamlik Smit (2007:138); Jackson (2008:63); Willingham (2007:4-5) en Hill (2001:390) bevestig dat skuldgevoelens 'n primêre emosionele belewenis is van die moeder na die onthulling van die seksuele misbruik van haar kind. Dit word ook as 'n fase van die rouproses (verlies) aangehaal, wat skuld impliseer. Jackson (2008:21) meen dat die moeder van die seksueel misbruikte kind na bekendmaking verskeie emosionele reaksies mag ervaar, naamlik vrees, woede, skuld, verwarring, verloëning en skok.

\section{- Nutteloosheid}

Die respondente behaal 'n persentasie van 23 in hierdie area, soos in Figuur 4 voorgehou. Vermelde dui op 'n waarskuwingsarea wat professionele hulp ten opsigte hiervan noodsaak. Die respondente beleef gevoelens van hulpeloosheid en magteloosheid en voel meermale nutteloos.

Die gevolgtrekking waartoe geraak kan word, is dat die respondente 'n behoefte aan selfontwikkeling binne die areas innerlike sekerheid en skuldgevoelens toon. Die respondente benodig professionele hulp ten opsigte van nutteloosheid.

\section{Respondente se belewing van inligting wat deur die forensiese maatskaplike werker verstrek is}

Hierdie inligting is verkry met behulp van die vraelys wat deur die navorser self ontwerp is.

'n Rol van die forensiese maatskaplike werker is om inligting rakende die forensiese proses aan die moeder beskikbaar te stel ten einde alternatiewe keuses rakende die forensiese proses voor te hou.

\section{- Verstrekking van inligting aan die respondente rakende die wetlike proses}

Die oorgrote meerderheid respondente, naamlik $11(73.3 \%)$, het gemeld dat die forensiese maatskaplike werker inligting rakende die wetlike prosesse en implikasies daarvan verstrek het, terwyl vier (4) respondente (26.7\%) vermeld het dat geen inligting deur die forensiese maatskaplike werker aan hulle beskikbaar gestel is nie. Die meerderheid respondente naamlik $10(66.5 \%)$ het gemeld dat die inligting wat deur die forensiese maatskaplike werker verstrek is voldoende was deurdat vrae beantwoord en onsekerhede uit die weg geruim is rakende die forensiese proses. Vyf (5) respondente, naamlik 33.5\%, het gemeen dat hulle nie genoeg inligting ontvang het met betrekking tot die forensiese proses ten einde vrae te beantwoord en onsekerhede uit die weg te ruim nie. Hierdie vyf (5) respondente het bepaalde verduidelikings gegee vir hul persepsies, naamlik: 
Ek was in 'n skoktoestand en kan nie al die inligting onthou of verwerk nie.

Die maatskaplike werker van die welsynsorganisasie het net my kind gevat en gesê dat my kind gemolesteer word.

My kind is verwyder nadat sy forensies geëvalueer is. Ek het nie terugvoer verkry nie, maar is eers later meegedeel wat gebeur het.

Ek het nie voldoende terugvoer gekry nie, omdat die wetlike proses nog besig was.

Geen verduideliking is deur die vyfde respondent gegee wat gemeen het dat sy nie genoeg inligting ontvang het nie.

\section{Verstrekking van inligting sodat die respondent 'n ingeligte besluit kon neem rakende haar kind se toekoms}

Die oorgrote meerderheid respondente, naamlik $11(73.3 \%)$, het gemeld dat hulle voldoende inligting van die maatskaplike werker ontvang het ten einde ' $n$ ingeligte besluit te kon neem oor hul kind se toekoms. Vier (4) respondente $(26.7 \%)$ het gemeen dat hulle nie genoeg inligting van die forensiese maatskaplike werker ontvang het, om 'n ingeligte besluit rakende hul kinders te kon neem nie.

Die respondente het bepaalde response verleen met betrekking tot hierdie vraag ter verduideliking:

Ek besef die bindingsverhouding tussen my en my kind het skade gely. Ek moet my kind help.

Die inligting wat my kind gee, is die waarheid. Ek moet nou optree. Dit was vir my genoeg om bevestiging te kry by die forensiese maatskaplike werker.

Inligting wat verkry is, was voldoende maar die trauma wat my kind ervaar, is 'n probleem.

Die kriminele saak is nog hangende. Ek is nog onseker daaroor, maar die inligting was voldoende.

Ek het tersaaklike inligting gekry en het besluit om hom krimineel te vervolg. Die hofsaak hou nou so lank al aan dat dit my kind geweldig ontstel. Hy word met die beskuldigde gekonfronteer.

\section{Die respondente se belewenis van die forensiese proses binne die maatskaplikewerk-perspektief}

Die oorgrote meerderheid, naamlik nege (9) van die respondente, het positiewe response gelewer met betrekking tot hul belewenis van die forensiese proses binne die maatskaplikewerk-perspektief:

Die ouer en kind moet hulp ontvang. Ek glo dat dit die forensiese proses sal vergemaklik.

Brits en Joubert (2003:30) meld dat die betrokkenheid van die nie-oortredende ouers of betekenisvolle persone by die terapeutiese proses, sterk benadruk moet word. Vroeë intervensie deur die betrokke professionele persone, versterk 'n positiewe prognose by die seksueel misbruikte kind en ondersteunende ouer (Jinich \& Litrownik 1999:176; Smit, 2007:147; Vermeulen \& Fouché, 2006:14).

Die inligting was vir my 'n geweldige skok. Dit was oorweldigend. Ek het berading benodig om daar te wees vir my kinders. 
Sanders, Cann en Markie-Dadds (2003:155) meen dat nie-oortredende ouers in behandelingsprogramme ondersteun moet word wat bepaalde aspekte behoort te behandel, naamlik "[e]nhance the knowledge, skills, confidence, self-sufficiency, copying skills and resourcefulness of parents. It should promote nurturing and safe environments for their children. The child's social, emotional and intellectual needs should be met in their environment".

Ek het die forensiese proses as geloofwaardig ervaar.

Die forensiese maatskaplike werker het my bygestaan terwyl ek onseker was oor die inligting wat my kind gegee het. Sy het my ondersteun.

Ek het beleef dat die forensiese maatskaplike werker ervaring het en in staat was om akkurate inligting te gee met betrekking tot my kind.

Die forensiese proses was objektief en alles-omsluitend. Die beskikbare inligting was bestudeer en geёvalueer. Daar is op alle terreine na my kind omgesien.

Ek was geskok en verbaas tydens die proses. Ek glo die forensiese maatskaplike werker het die proses goed hanteer.

Die forensiese proses was voldoende omdat alle inligting rakende die seksuele misbruik na vore gekom het.

Die forensiese proses het vinnig afgeloop. Ek was tevrede daarmee.

Drie (3) van die respondente het die forensiese proses, gesien vanuit 'n maatskaplike perspektief, negatief beleef:

Ek was nie betrokke by die forensiese proses nie - my kind is verwyder sonder enige verduideliking.

Ek het skuldig gevoel en was geskok. Ek wou terugvoer kry maar het nie direkte kontak met die forensiese maatskaplike werker gehad nie, slegs met die maatskaplike werker van die welsynsorganisasie. Dit was onbevredigend. Ek is nou nog kwaad.

Ek het gevoel dat ek nie ingelig was nie. My kind is verwyder na die forensiese assessering. Ek is net gelos om aan te gaan sonder die nodige inligting.

Die vorige drie (3) respondente se ervaring sluit aan by dit wat Jackson (2008:56) uitwys, naamlik dat "... the disclosure of sexual abuse sets off a crisis of intervention from child protective services, law enforcement, the court ... the non-offending parent is left feeling stigmatized, frightened, confused and angry".

Twee (2) van die respondente se response in hierdie verband dui op intense spanning wat beleef was tydens die forensiese proses, naamlik:

Die forensiese proses was emosioneel uitputtend. Ek het wel duidelikheid gehad oor wat volgende sou gebeur.

Die forensiese proses het my uitgemergel. Ek wou probeer staande bly vir my kind. Ek wou haar help.

Uit voormelde response is dit duidelik dat sommige respondente die forensiese proses meer traumaties beleef het as ander. Die trauma by hierdie respondente was gesetel in die verhouding tussen die respondent en die oortreder asook die wyse waarop die statutêre proses na die bekendmaking van seksuele misbruik verloop het. Die respondente wat daarop wys dat die proses uitmergelend was, was getroud met die oortreder. Van die respondente se kinders is ná die forensiese assessering verwyder, wat die moeders verder getraumatiseer het. 


\section{Respondente se voorstelle ten opsigte van hulp deur die forensiese maatskaplike werker binne die wetlike proses}

Al die respondente (dus 100\%) het gemeld dat die forensiese maatskaplike werker verplig moet word om die moeder met haar kind vir terapie te verwys. Al die respondente het gemeen dat hulle tydens die forensiese proses berading benodig het. Jackson (2008:58) is van mening dat terapeutiese intervensie ten opsigte van die nie-oortredende ouer noodsaaklik is weens die impak van die bekendmaking van die seksuele misbruik op die ouer se algehele funksionering. In die gevalle waar die forensiese maatskaplike werker self terugvoer aan die moeders gegee het, is die moeder en die kind vir terapie verwys. Ses (6) respondente het, nadat die forensiese maatskaplike werker dit voorgestel het, genoem dat hulle die waarde van terapie vir hulself en hul kinders besef het. Drie (3) respondente het slegs opgemerk dat die inligting wat hulle ontvang het, voldoende was.

In gevalle waar die statutêre maatskaplike werker tot die saak toegetree het, was die moeder en kind nie vir terapie verwys nie. Hierdie moeders, vier (4) respondente, het geantwoord dat hulle nie tersaaklike inligting ontvang het nie en nie in die saak geken is nie. Twee (2) respondente het geen verdere voorstelle in hierdie verband gemaak nie.

Die forensiese maatskaplike werker se posisie binne die forensiese proses word deur Kuehnle (1996:32) beskryf as dat dit neutraal moet wees. Interne afhanklikheid is dus van die uiterste belang aangesien die professionele persoon maklik sy/haar grense kan oorskry en dan benewens sy/haar eie rol as assesseerder, ook dié van die terapeut oorneem.

As gevolg van die potensiële konflik tussen die rol van die terapeut en dié van die forensiese assesseerder is dit belangrik dat die forensiese maatskaplike werker nie haar professionele beroepsgrense moet oorskry nie. Die forensiese maatskaplike werker mag dus in geen stadium empaties of terapeuties by die kind betrokke raak nie (Grobbelaar, 2008:8).

Geen inligting is egter beskikbaar rakende die forensiese maatskaplike werker se betrokkenheid by die moeder met betrekking tot die oorskryding van professionele grense nie. Die navorser is van mening dat die forensiese maatskaplike werker die moeder van die misbruikte kind so spoedig moontlik vir terapeutiese hulp moet verwys. Die navorser huldig hierdie mening om die volgende redes:

- Omdat die moeder onmiddellike en terapeutiese ondersteuning van 'n professionele persoon moet ontvang. Sodoende beskerm die forensiese maatskaplike werker haar/sy interne onafhanklikheid en betrokkenheid by die moeder se trauma. Emosionele betrokkenheid van die forensiese maatskaplike werker by die moeder kan teenoordrag tot gevolg hê, wat die forensiese proses kontamineer. Die terapeut behoort dus alle inligting ten opsigte van die terapeutiese proses aan die moeder oor te dra.

- Omdat die moeder van die seksueel misbruikte kind die nodige terapie moet ontvang, sodat sy haar kind toepaslik kan ondersteun.

Die verstrekking van toepaslike inligting is deur die moeder van die seksueel misbruikte kind genoem as synde 'n rol wat die forensiese maatskaplike werker behoort te vervul.

Die forensiese maatskaplike werker behoort te konsentreer op inligting wat vir die forensiese of statutêre proses toepaslik is, naamlik:

- Verwysing na 'n SAPD-ondersoekbeampte wat spesialiseer in die ondersoek van misdade teen kinders. 
- Verwysing na 'n terapeut of instansie wat kinders en ouers voorberei met die oog op hof prosedures. Ontlonting ná hof prosedures is ook belangrik.

- Verwysing na 'n forensiese mediese dokter indien van toepassing.

Ten slotte meld Jinich en Litrownik (1999:176) dat "[i]t is clear that there is a need to develop and evaluate interventions aimed at helping the parent of molested children cope with the initial crisis surrounding disclosure. Such information should provide parents with specific information regarding their own emotional functioning”.

\section{AANBEVELINGS}

Op grond van die bevindinge, word die volgende aanbevelings aan die hand gedoen:

- Die forensiese maatskaplike werker behoort haar te vergewis van die rol wat sy binne die forensiese en statutêre proses vervul ten aansien van die moeder van die seksueel misbruikte kind na bekendmaking van die oortreding.

- Die forensiese maatskaplike werker behoort onder geen omstandighede 'n terapeutiese rol te vervul rakende die moeder of seksueel misbruikte kind nie weens moontlike kontaminasie van die forensiese proses.

- Die forensiese maatskaplike werker behoort haar te vergewis van die hantering van die moeder wat met intense emosie reageer, na die onthulling van die seksuele misbruik van haar kind.

- Die forensiese maatskaplike werker behoort die moeder reeds in die vroeë stadium van die forensiese proses vir terapeutiese intervensie te verwys. Die moeder kan binne 'n terapeutiese konteks toepaslike hulp rakende emosionele trauma ontvang en bygestaan word ten opsigte van die hantering van die seksueel misbruikte kind.

- Die forensiese maatskaplike werker behoort inligting rakende die wetlike of statutêre prosesse aan die moeder oor te dra. Indien kinderhofverrigtinge genoodsaak word, behoort die moeder ten opsigte van die proses ingelig te word.

- Die forensiese maatskaplike werker behoort die moeder, indien van toepassing, na 'n SAPDbeampte wat in die ondersoek van misdade teen kinders spesialiseer, te verwys.

- Die ondersoekbeampte (SAPD) behoort volgehoue terugvoer aan die ouers rakende die verloop van die SAPD-ondersoek te gee tot wanneer die saak aan die staatsaanklaer vir vervolging al dan nie voorgelê word.

- Die forensiese maatskaplike werker behoort die inligting rakende die stappe wat tydens die forensiese proses gevolg word, vir die moeder uiteen te sit. Verder sal 'n verduideliking van die doel van die voormelde stappe aan die moeder meer beheer gee binne die konteks waarin sy funksioneer.

- 'n Verwysing na 'n forensiese mediese dokter is noodsaaklik aangesien so 'n deskundige bevoeg is om bepaalde bevindinge aan die hand van mediese navorsing te verduidelik. Die forensiese mediese dokter sal dan bykomende inligting aan die moeder kan gee, wat bepaalde onsekerhede kan opklaar en antwoorde op vrae kan gee.

- Die forensiese maatskaplike werker behoort ander professionele persone, met spesifieke verwysing na die statutêre maatskaplike werker, toepaslik binne die forensiese konteks in te lig rakende die posisie van die moeder van die seksueel misbruikte kind. 


\section{LEEMTES WAT VOORGEKOM HET TEN OPSIGTE VAN DIE NAVORSINGS-PROSES}

Delport en Fouché (2005:353) is van mening dat die navorser binne die kwalitatiewe konteks sy/haar waardes, vooroordele en posisie in die navorsingsverslag moet aandui. Beperkinge en leemtes word vervolgens voorgehou:

- Die steekproef was relatief klein en subjektief gegewe die werwingsmetode. Bevindinge kan dus nie veralgemeen word na alle moeders van seksueel misbruikte kinders nie.

- Die navorser is as forensiese maatskaplike werker gemoeid met die forensiese assessering van kinders. Uit hoofde van hierdie realiteit word die navorser gekonfronteer met die moeders van seksueel misbruikte kinders. Aangesien hierdie moeders na bekendmaking van seksuele misbruik by hul kinders met bepaalde emosionele response presenteer, het die navorser die navorsingsterrein met sekere vooropgestelde persepsies betree.

- Tydens die invul van die selfontwerpte vraelys het die respondente in gesprek begin tree met mekaar, wat beïnvloeding tot gevolg kon gehad het. Voormelde kon dus tot gevolg gehad het dat die respondente mekaar kon beïnvloed het rakende die invul van die selfontwerpte vraelys.

- Die emosionele funksionering van die moeder van die seksueel misbruikte kind is nie voor die bekendmaking van seksuele misbruik deur die gestandaardiseerde meetinstrument vasgestel nie. Voormelde impliseer dat daar dus nie 'n vergelyking getref kon word tussen die respondente se emosionele funksionering voor en na hul kinders se bekendmaking van seksuele misbruik nie.

\section{SAMEVATTING}

Die studie is onderneem ten einde die moeder van die seksueel misbruikte kind se emosionele reaksies te bepaal en hoedat die forensiese maatskaplike werker die moeder tydens die forensiese proses behulpsaam kan wees.

Aan die hand van 'n empiriese ondersoek is uitgewys dat forensiese maatskaplike werkers bepaalde funksies ten aansien van die moeder van die seksueel misbruikte kind behoort te verrig.

Die sentrale teoretiese stelling, naamlik dat die moeder van die seksueel misbruikte kind na die onthulling van die oortreding met simptome van trauma presenteer, en die forensiese maatskaplike werker dus onder 'n verpligting staan om bepaalde insette rakende die moeder te lewer, is bevestig.

Hierdie projek is uitgevoer binne die navorsingsprojek: Maatskaplike Werk in Forensiese Praktyk onder leiding van C Wessels en is befonds deur die navorsingseenheid AUTHeR.

\section{BIBLIOGRAFIE}

BABBIE, E. 2007. The practice of social research. London: Thomson \& Wadworth.

BARKER, R.L. 2003. The Social Work Dictionary. Washington DC: NASW Press.

BARKER, R.L. \& BRANSON, D.M. 2000. Forensic social work. New York: Haworth Press.

BRITS, L. \& JOUBERT, J.M.C. 2003. 'n Voorgestelde intervensie model vir die seksueel misbruikte kind. CARSA, 4(2):30. 
CAWOOD, L. 2004. Childline's research report. Johannesburg: Childline Crisisline. [Online] Available: http://www.childline.org.za [Accessed: 04/052009].

DELPORT, C.S.L. 2005. Quantitative data collection methods. In: DE VOS, A.S., STRYDOM, H., FOUCHÉ, C.B. \& DELPORT, C.S.L. Research at grass roots for the social sciences and human service professions. Pretoria: Van Schaik Publishers: 159-191.

DYB, G., HOLEN, A., STEINBERG, A.M., RODERIGUEZ, N. \& PYNOOS, R.S. 2003. Alleged sexual abuse at a day care centre: impact on parents. Child Abuse \& Neglect, 27(3):939-950.

FAUL, A.C. \& HANEKOM, A.J. 2006. Ekometrie Module 2. Potchefstroom: Perspective Training College.

FOUCHÉ, C.B. \& DELPORT, C.S.L. 2005. In-depth review of literature. In: DE VOS, A.S., STRYDOM, H., FOUCHÉ, C.B. \& DELPORT, C.S.L. Research at grass roots for the social sciences and human service professions. Pretoria: Van Schaik Publishers: 123-131.

GROBBELAAR, A. 2008. Inleiding tot forensiese maatskaplike werk met spesifieke verwysing na seksuele- en fisiese misbruik van kinders. (Lesing gelewer as deel van die kursus in MWKF 876 vir Meestersgraadstudente aan die PU vir CHO in Februarie 2008.) Potchefstroom. (Ongepubliseer)

HIEBERT-MURPHY, D. 1998. Emotional distress among mothers whose children have been sexually abused: the role of a history of child abuse, social support and coping. Child Abuse \& Neglect, 22(5):423-435.

HILL, A. 2001. "No-one else could understand": Women's experiences of a support group run by mothers of sexually abused children. British Journal of Social Work, 31(1):385-397.

JACKSON, C.J. 2008. Forgotten victims: mothers of sexually abused girls. United States: Capella University. (DPhil Thesis)

JINICH, S. \& LITROWNIK, A.J. 1999. Coping with sexual abuse: development and evaluation of a video tape intervention for non-offending parents. Child Abuse \& Neglect, 23(2):175-176.

KRUGER, D.J., DE VOS, A.S., FOUCHÉ, C.B. \& VENTER, L. 2005. Quantitative data analysis and interpretation. In: DE VOS, A.S., STRYDOM, H., FOUCHÉ, C.B. \& DELPORT, C.S.L. Research at grass roots for the social sciences and human service professions. Pretoria: Van Schaik Publishers: 217-245.

KUEHNLE, K. 1996. Assessing allegations of child sexual abuse. Sarasota: Professional Resource Press.

LE ROUX, J. 2000. Causes of child abuse: what does the literature indicate? CARSA, 1(2):3640 .

MARShall, A. \& HERMAN, V. 2000. Child sexual abuse in South Africa - a book by RAPCAN. Cape Town: L.P. Printers.

NUWE WOORDEBOEK VIR MAATSKAPLIKE WERK. 1995. Kaapstad: CTP Book Printers.

NEUMAN, W.L. 2000. Social research methods: qualitative and quantitative approaches. London: Allyn \& Bacon. 
PLUMMER, C.A. 2006. The discovery process: what mothers see and do in gaining awareness of the sexual abuse of their children. Child Abuse \& Neglect, 30(1):1227-1237.

ROSENTHAL, S., FEIRING, C. \& TASKA, L. 2003. Emotional support and adjustment over a year's time following sexual abuse discovery. Child Abuse \& Neglect, 27(3):641-661.

SANDERS, R.M., CANN, W. \& MARKIE-DADDS, C. 2003. The Triple P-Positive Parenting Programme: a universal population-level approach to the prevention of child abuse. Child Abuse Review, 12(3):155-171.

SMIT, A.H. 2007. Adolescents' experiences of parental reaction to the disclosure of child sexual abuse. Pretoria: University of Pretoria (Unpublished MA Thesis)

STRYDOM, C. \& LUDWIG, C. 2009. 'n Ondersoek na opleidingsgeleenthede vir spesialisasie in forensiese maatskaplike werk. Social Work/Maatskaplike Werk, 45(3):327-342.

STRYDOM, H. 2005a. Ethical aspects of research in social sciences and human service professions. In: DE VOS, A.S., STRYDOM, H., FOUCHÉ, C.B. \& DELPORT, C.S.L. Research at grass roots for the social sciences and human service professions. Pretoria: Van Schaik Publishers: 56-69.

STRYDOM, H. 2005b. Sampling and sampling methods. In: DE VOS, A.S., STRYDOM, H., FOUCHÉ, C.B. \& DELPORT, C.S.L. Research at grass roots for the social sciences and human service professions. Pretoria: Van Schaik Publishers: 192-204.

STRYDOM, H. 2005c. The pilot study. In: DE VOS, A.S., STRYDOM, H., FOUCHÉ, C.B. \& DELPORT, C.S.L. Research at grass roots for the social sciences and human service professions. Pretoria: Van Schaik Publishers: 205-216.

VERMEULEN, A. \& FOUCHÉ, C.B. 2006. The relevance of family structure to the victimperpetrator relationship in child sexual abuse in South Africa. Child Abuse Research in South Africa, 7(1):14-23.

WEYERS, M.L. 2001. Demarcating the field of forensic social work in South Africa: a basic document. (Document presented to the SACSSP in July 2001 by the School for Psychosocial Behavioural Sciences: Social Work Division Potchefstroom University for CHE) Potchefstroom. (Unpublished)

WILLINGHAM, E.U. 2007. Maternal perceptions and responses to child sexual abuse. Atlanta: Georgia State University. (DPhil Thesis)

Dr Corinne Strydom, Skool vir Psigo-sosiale Gedragswetenskappe, Potchefstroomkampus van die Noordwes-Universiteit, Potchefstroom; Me Wilna J. Stander, 'n Meestersgraadstudent in Forensiese Praktyk aan die Noordwes-Universiteit (Potchefstroomkampus) en werksaam as privaat maatskaplike werker gemoeid met Forensiese Maatskaplike Werk, Pretoria, Gauteng, Suid-Afrika. 